\title{
QUALITY CHARACTERISTICS AND ANTIOXIDANT ACTIVITY OF JUICES PRODUCED WITH IRRADIATED GRAPES ${ }^{1}$
}

\author{
ANA CAROLINA VILAS BOAS², RITA DE CÁSSIA MIRELA RESENDE NASSUR ${ }^{3}$, \\ JULIANA MESQUITA FREIRE ${ }^{4}$, ANTÔNIO DECARLOS NETO 5 , \\ LUIZ CARLOS DE OLIVEIRA LIMA ${ }^{6}$
}

ABSTRACT- The aim of this study was to evaluate physicochemical characteristics, antioxidant activity, total phenolic, vitamin $\mathrm{C}$ and anthocyanins content of grape juices from cv. Isabel submitted to different UV-C doses. The fruits were harvested, sanitized and inserted into a UV-C radiation chamber, where different doses were applied: $0 \mathrm{~kJ} / \mathrm{m}^{2}$ (0 minutes); $0.68 \mathrm{~kJ} / \mathrm{m}^{2}$ (2 minutes); $2.73 \mathrm{~kJ} / \mathrm{m}^{2}$ (4 minutes); $4.10 \mathrm{~kJ} / \mathrm{m}^{2}$ (6 minutes). The grape juice was extracted at $75 \pm 5^{\circ} \mathrm{C}$ for 1 hour, using an equipment with steam extraction and submitted to evaluations after $0,30,60$ and 90 days of cold storage. No significant differences were observed in grape juices submitted to radiation doses regarding the antioxidant activity and phenolic compounds. However, the vitamin C content was affected by different UV-C doses, where there was an increase in the values of the treated fruits during storage.

Index terms: Vitis labrusca, phenolic compounds, vitamin C, quality, irradiation.

\section{CARACTERIZAÇÃO FÍSICO-QUÍMICA E ATIVIDADE ANTIOXIDANTE DE SUCOS ELABORADOS A PARTIR DE UVAS IRRADIADAS}

RESUMO- O presente trabalho teve como objetivo a caracterização físico-química, bem como a avaliação da atividade antioxidante, teor de fenólicos totais, vitamina $\mathrm{C}$ e antocianinas de sucos elaborados a partir de uvas cultivar Isabel submetidas a diferentes doses de radiação UV-C. Os frutos foram colhidos, sanitizados e inseridos em uma câmara de radiação UV-C, onde diferentes doses foram aplicadas: $0 \mathrm{KJ} / \mathrm{m}^{2}(0$ minutos $)$; $0,68 \mathrm{KJ} / \mathrm{m}^{2}$ (2 minutos); $2,73 \mathrm{KJ} / \mathrm{m}^{2}$ (4 minutos); $4,10 \mathrm{KJ} / \mathrm{m}^{2}$ (6 minutos). A elaboração dos sucos de uva foi realizada a $75^{\circ} \pm 5^{\circ} \mathrm{C}$ durante 1 hora, usando um equipamento artesanal por arraste de vapor e os mesmos foram analisados após 0, 30, 60 e 90 dias de armazenamento. Os sucos de uva não apresentaram diferenças significativas com relação às doses de radiação para atividade antioxidante e compostos fenólicos. Porém, o teor de vitamina $\mathrm{C}$ foi afetado pelas diferentes doses, onde observou-se um aumento dos valores dos frutos tratados ao longo do armazenamento.

Termos para indexação: Vitis labrusca, compostos fenólicos, vitamina C, qualidade, irradiação.

\footnotetext{
1(Paper 251-15). Received November 03, 2015. Accepted May 13, 2016.

${ }^{2}$ Phd in Food Science, Federal University of Lavras, e-mail: vbanacarolina@yahoo.com.br

${ }^{3}$ Phd in Food Science, Professor of the Department of Technology and Social Sciences, Bahia State University. E-mail: ritarnassur@ hotmail.com

${ }^{4}$ Phd, Professor of the Department of Chemistry, Federal University of Lavras. E-mail: mesquitafreire@yahoo.com.br

${ }^{5}$ Phd, Professor of the Department of Agriculture, Federal University of Lavras. E-mail: adecarlos@dag.ufla.br

${ }^{6}$ Phd, Professor of the Department of Food Science, Federal University of Lavras. E-mail: 1colima@dca.ufla.br
} 


\section{INTRODUCTION}

Grape juices are food products rich in phenolic compounds. Grape consumption and its derivatives are associated with several beneficial health effects, such as: the increase of antioxidant capacity, reduction of oxidized low density lipoproteins (LDL), increase of high density lipoproteins (HDL) (EVANS et al., 2014), improvement of endothelial function (LI et al., 2013) antimutagenic activity (POLONIO et al., 2014), decrease in platelet aggregation (SCHAMATT et al., 2013), and improvement of cardiovascular oxidation (HORT et al., 2012) and neurocognitive function (KRIKORIAN et al., 2012).

Nowadays, consumers require not only safe products but also optimum nutritional quality. In this context, several recent researches have investigated the relation of the UV-C radiation with different quality parameters of fruits and vegetables, evaluating their possible effects and functional properties (BRAVO et al., 2012). The UV-C radiation is able to activate the plant defense mechanisms, which can interfere in the increase or maintenance of the concentration of nutritional compounds of interest to health, such as phenolic compounds, as well as increasing the antioxidant activity of different fruits (ALOTHMAN et al., 2009).

Several studies have been carried out to evaluate the use of UV-C radiation in fruit juice conservation (FREDERICKS et al., 2011; RAMESHKUMAR et al., 2012; PALA; TOKLUCU, 2013), as well as evaluating the content of phenolic compounds and antioxidant activity in grape juices (CHAUHAN et al., 2011; GENOVA et al., 2012; CAPANOGLU et al., 2013; AL BITTAR et al., 2013), however, there are no reports of the influence of different doses of UV-C radiation in grape juices from the cultivar Isabel produced in the Minas Gerais State, Brazil. Since the state of Minas Gerais is not traditionally known as a grape producer, studies aimed at the national insertion of the product and conservation strategies involving an increase or maintenance of the bioactive compounds present in this juice are necessary.

Therefore, the objective of this study was to verify the influence of different doses of UV-C radiation on the quality of grape juice cv. Isabel, as well as to evaluate the antioxidant activity, total phenolics, total anthocyanins and vitamin $\mathrm{C}$ contents during cold storage conditions.

\section{MATERIAL AND METHODS}

Grape juices from cv. Isabel were experimentally elaborated at the Postharvest Laboratory of the Federal University of Lavras (Lavras, MG, Brazil), using grapes from the 2013 crop year, grown in Minas Gerais. After harvest, the grapes were kept in a cold room at $10 \pm 2^{\circ} \mathrm{C}$ for 12 hours. Subsequently, the fruits were sanitized with $200 \mathrm{mg} \mathrm{L}^{-1}$ of sodium hypochlorite and the berries were carefully separated to avoid injuries. The fruits were inserted in a chamber of UV-C radiation, where different doses of radiation were applied: 0 $\mathrm{KJ} / \mathrm{m}^{2}$ (0 minutes); $0.68 \mathrm{KJ} / \mathrm{m}^{2}$ (2 minutes); 2.73 $\mathrm{KJ} / \mathrm{m}^{2}$ (4 minutes); $4.10 \mathrm{KJ} / \mathrm{m}^{2}$ (6 minutes). The radiation doses were measured through a portable spectroradiometer (USB-850 RED TIDE) coupled to a R400-7-VIS-NIR (US Bio Solutions Ocean Optics) probe and applied in an anti-reflective chamber. The distance between lamps and the irradiated material inside the chamber was $20 \mathrm{~cm}$, above and below the grapes. Four Ecolume $15 \mathrm{~W}$ 09/11 germicidal fluorescent lamps were used in the process. The dose was calculated by integrating exposure time and source power (DIFFEY, 2002).

The elaboration of the grape juice was carried out at $75 \pm 5^{\circ} \mathrm{C}$ for 1 hour, using an equipament based on extraction with steam, according to Rizzon et al. (1998). For each liter of grape juice, $0.8 \mathrm{~g}$ of potassium metabisulfite (Synth, Diadema, Brazil) was added. After this step, the juices were immediately bottled in $100 \mathrm{ml}$ glass vials and kept under cold storage $\left(18 \pm 2^{\circ} \mathrm{C}\right)$ until analysis.

The following analyzes were performed after $0,30,60$ and 90 days of storage: soluble solids, $\mathrm{pH}$, titratable acidity, soluble solids / titratable acidity ratio, vitamin $C$, total phenolics, total anthocyanins and antioxidant activity (DPPH and $\beta$ - Carotene / linoleic acid).

The total soluble solids (SS) of the juices were determined using an ATAGO PR-100 digital refractometer, being the results expressed in \%, according to the AOAC recommendation (2007). The $\mathrm{pH}$ measurement was carried out using a Tecnal $\mathrm{pH}$ meter (Tec $3 \mathrm{M})$ with glass electrode, according to the recommendations of the Association of Official Analytical Chemists (AOAC, 2007). The titratable acidity (TA) was also determined by a methodology suggested by AOAC (2007), titrating with $0.1 \mathrm{~mol} \mathrm{~L}^{-1}$ of a sodium hydroxide solution $(\mathrm{NaOH})$, being the results expressed as \% of tartaric acid. To calculate the SS/TA ratio, the total soluble solids content was 
divided by the titratable acidity of the samples.

The levels of vitamin $\mathrm{C}$ were quantified by a colorimetric method using 2,4 dinitrophenylhydrazine, according to Strohecker and Henning (1967). The reading was performed at $520 \mathrm{~nm}$ using a Beckman 640B spectrophotometer. The results were expressed as $\mathrm{mg}$ of ascorbic acid per $100 \mathrm{~mL}^{-1}$ of juice.

The total phenolics were obtained according to the colorimetric method developed by Singleton and Rossi (1965), using the Folin-Ciocalteu reagent, in $10 \%(\mathrm{v} / \mathrm{v})$ solution. The extraction procedure involved consecutive steps of centrifugation and filtration aiming to obtain a better extraction of the phenolic compounds, as described by Larrauri et al. (1997).

The determination of the antioxidant activity of the juices was carried out according to the scavenging of the DPPH (2,2-diphenyl-1-picrylhydrazyl) radical, according to Rufino et al. (2007a). To determine the antioxidant activity, the extracts used to determine the total phenolics were used, as suggested by Larrauri et al. (1997). For comparison purposes, the percentage of free radical scavenging (\%FRS) was calculated according to the formula suggested by Duarte-Almeida et al. (2006): \% FRS = (Ac-Am) x $100 /$ Ac, where Ac (control Abs) and Am (sample Abs). In this parameter, high values indicate a higher antioxidant capacity of the studied sample.

The evaluation of the antioxidant activity of the juices by the $\beta$-carotene / linoleic acid method followed a protocol recommended by Rufino et al. (2007b). The sample extract was obtained according to the methodology of Larrauri et al. (1997). The results were expressed as $\%$ of protection against oxidation.

The analysis of the total anthocyanin content was performed following the differential $\mathrm{pH}$ method, proposed by Giusti and Wrolstad (2001), and the results expressed in $\mathrm{m} \mathrm{L}^{-1}$.

The experiment was carried out in a completely randomized design (CRD) in a $4 \times 4$ factorial scheme, with four doses of UV-C radiation and four storage periods $(0,30,60$ and 90 days), with 3 replicates. The Tukey test at 5\% probability was used to compare the treatments within each time. The polynomial regression models, used for storage time, were selected based on the significance of the $F$ test of each tested model and the coefficient of determination.

\section{RESULTS AND DISCUSSION}

The physico-chemical characteristics of the processed products are extremely important as it provides information on the quality and factors that may interfere in the acceptability of the product by the consumer. Table 1 shows the content of soluble solids in juices of grapes submitted to different doses of UV-C radiation.

When the time was evaluated, the content of soluble solids content did not present significant differences ion to time, but the difference was observed among treatments, and juices submitted to the dose of $0.68 \mathrm{KJ} / \mathrm{m}^{2}$ presented the highest mean values (Table 1). For this parameter, all the juices presented below the level established by the Brazilian legislation, which is $14^{\circ}$ Brix (BRASIL, 1998). Rizzon and Link (2006), when carrying out a characterization of Isabel grape juices, also observed a soluble solids content below that established by legislation, with mean values of $12.9^{\circ}$ Brix.

Figure 1 shows the values of $\mathrm{pH}$ and titratable acidity of Isabel cultivar juice submitted to different doses of UV-C radiation.

The $\mathrm{pH}$ presented an increase, especially at 30 and 60 days of storage, and at 90 days, the juices showed no difference between the applied treatments. According to the values of titratable acidity, the grapes submitted to the dose of $4.10 \mathrm{KJ} / \mathrm{m}^{2}$ presented a lower content of tartaric acid, presenting average values of $0.91 \%$. These values show that all the juices were above the minimum standards established by the Brazilian legislation for acidity, which is $0.49 \%$ (BRASIL, 1998). Pala and Toklucu (2013), studying white grape juices and UV-C $(12.6 \mathrm{~J} / \mathrm{mL}$ and 25.2 $\mathrm{J} / \mathrm{mL}$ ) treatments, did not observed significant differences in $\mathrm{pH}$ values and titratable acidity.

The presence of acidity in grape juice is due to the content of organic acids, with predominance of tartaric, malic and citric acids, also varying according to the studied cultivar (GIRARD; MAZZA, 1998) .The soluble solids/titratable acidity ratio shows a balance between the sweet and acidic flavors of the elaborated juices, being related, among other factors, to the grape cultivar used. It was possible to observe that this variable did not present differences regarding the treatments (Figure 1), differing only according to the time of storage, presenting mean values of 9.47 for the last time of evaluation. It is important to observe that the Brazilian legislation recommends the SS/TA ratio values be between 15 and 45 (BRAZIL, 1998), and that all observed values for 
this variable in the present research were below the expected, as a consequence of a lower soluble solids content. Rizzon and Link (2006), when evaluating the physical-chemical characteristics of Isabel grape juices, observed a lower SS/TA ratio than the juices from other grape cultivars, such as Concord.

Figure 2 presents the vitamin $\mathrm{C}$ content and total phenolics of grape juice submitted to different doses of UV-C radiation.

The content of vitamin $\mathrm{C}$ showed significant differences in the time-treatment interaction, and on the last day of storage, juices from grapes submitted to UV-C radiation in the dose of $0.68 \mathrm{KJ} / \mathrm{m}^{2}$ presented higher values reaching $45.49 \mathrm{mg} 100 \mathrm{~mL}^{-1}$. The control group presented a reduction of vitamin $\mathrm{C}$ levels according to the time of storage, reaching

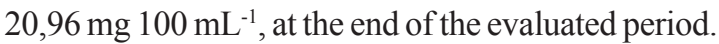
This fact evidences the positive influence of radiation doses on the maintenance of vitamin $\mathrm{C}$ contents in grape juices stored for 90 days, since at the end of the storage time, all doses had higher values of vitamin $\mathrm{C}$ than the control group.

The total phenolic content (Figure 2) showed significant differences over time, but not between the treatments, reaching mean values of $290.26 \mathrm{mg} 100$ $\mathrm{mL}^{-1}$. These results are in agreement with Pala and Toklucu (2013), who also did not observe significant differences in the total phenolics content between control juices and treated with UV-C radiation (12.6 $\mathrm{J} / \mathrm{mL}$ and $(25.2 \mathrm{~J} / \mathrm{mL})$.

It is important to emphasize that fruits and their products are the main dietary sources of polyphenols, presenting a varied quantitative and qualitative composition of these constituents, due to intrinsic factors such as cultivar, variety and stage of maturation, and extrinsic, such as climatic and edaphic conditions, emphasizing that the efficacy of the antioxidant action depends on the chemical structure and concentration of these phytochemicals in the food (MELO et al., 2008).

The total anthocyanins content of grape juices presented differences over time (Figure 3), showing a reduction along the refrigerated storage, as well as between the treatments (Table 2), and the control group presented the highest values. During food processing, there are some limitations in using UV radiation. When the product is submitted to UV radiation, the surface pigments may undergo photodegradation (Guerrero-Belrand et al., 2009), a fact that may have occurred with the grapes that went through this physical process before juices were produced. Moreover, the natural electron deficiency of anthocyanins makes these compounds particularly reactive, also presenting a great sensitivity to changes in $\mathrm{pH}$ and temperature (VOLP et al., 2008). The values of anthocyanins found in the present study are within the range of values found by Vilas Boas et al. (2014), studying grape juices of different cultivars produced in Minas Gerais and observed anthocyanin levels ranging from 120.95 to $1004.35 \mathrm{mg} \mathrm{L}^{-1}$.

The antioxidant activity of grape juices did not presented differences according to the radiation doses, varying only according to storage time for both analyzed methods, reaching average values of $24.83 \%$ and $49.25 \%$ for $\%$ of free-radicals scavenging and $\%$ of protection, respectively, for the last evaluated period. Shen et al. (2013), studying minimally processed tangerine submitted to different doses of UV-C, observed that phenolic acids and antioxidant capacity were not significantly affected by the use of radiation. An increase of total flavonoids and phenolics were observed in fruits treated with 1.5 and $3.0 \mathrm{KJ} / \mathrm{m}^{2}$ in the first 3 days, reducing the contents after 4 days of storage. 



FIGURE 1 - pH, total acidity and soluble solids/acidaty ratio of juices from grapes submitted to different doses of UV-C radiation 

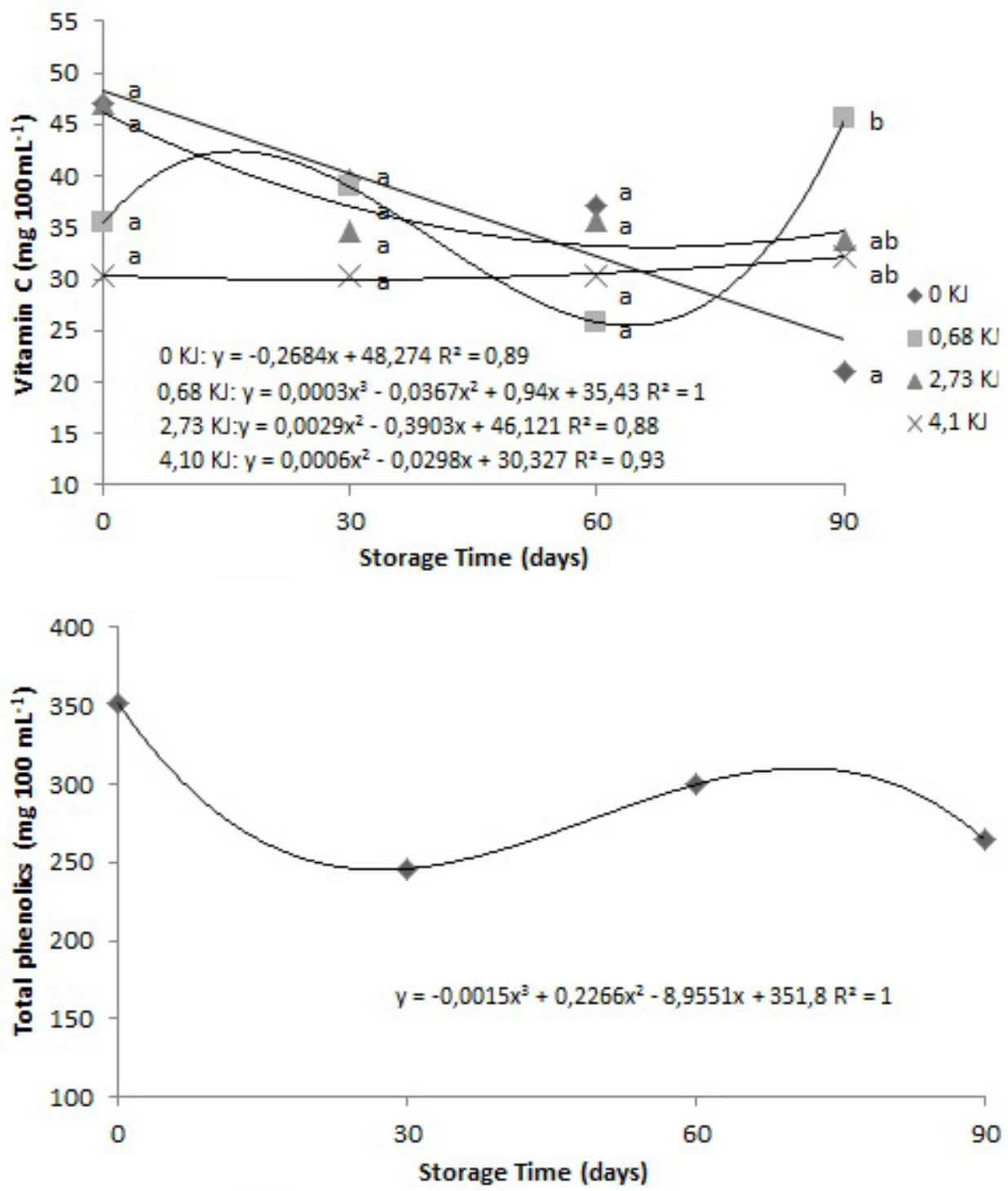

FIGURE 2 - Vitamin $\mathrm{C}$ and total phenolics contents of juices from grapes submitted to different doses of $\mathrm{UV}-\mathrm{C}$ radiation 


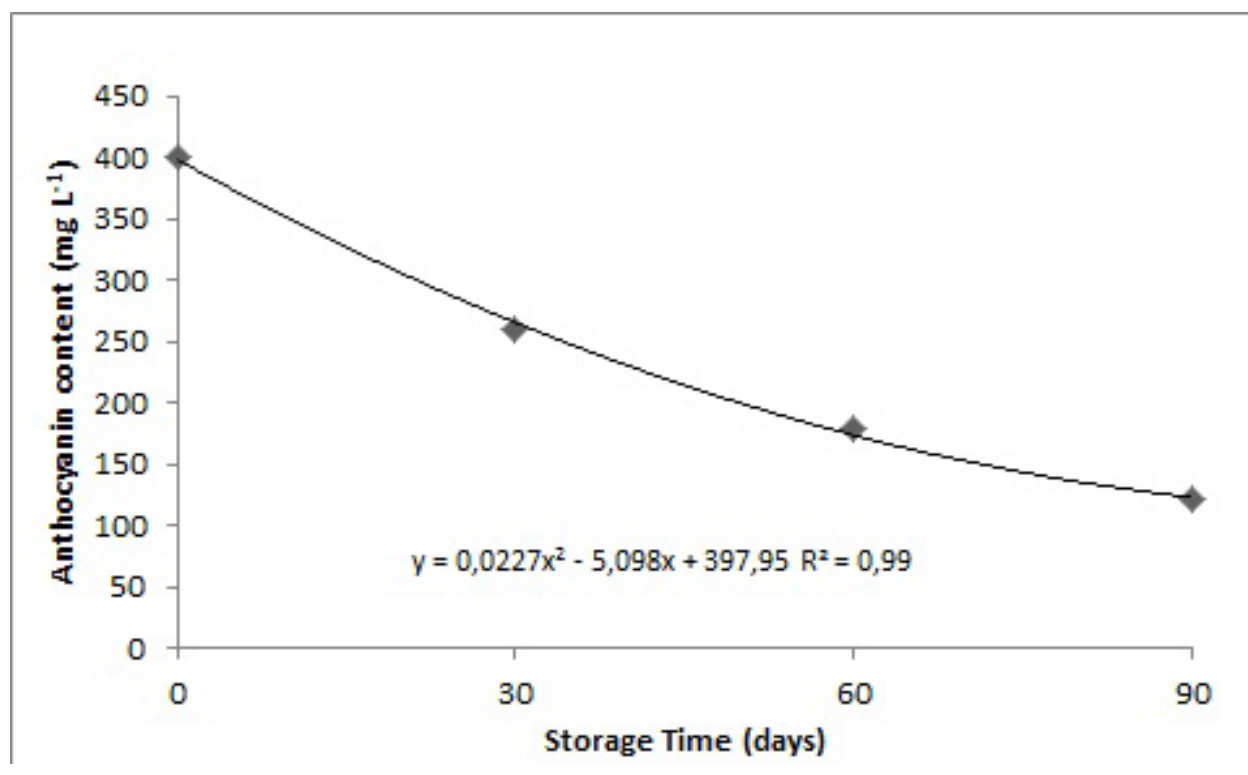

FIGURE 3 - Anthocyanin content of juices from grapes submitted to different doses of UV-C radiation.

TABLE 1 - Soluble solids content on grape juices submitted to different doses of UV-C radiation.

\begin{tabular}{c|c}
\hline UV-C doses & Soluble solids content (\%) \\
\hline $0 \mathrm{KJ}$ & $10.53 \mathrm{bc}$ \\
\hline $0.68 \mathrm{KJ}$ & $10.94 \mathrm{a}$ \\
\hline $2.73 \mathrm{KJ}$ & $10.65 \mathrm{bc}$ \\
\hline $4.10 \mathrm{KJ}$ & $9.25 \mathrm{c}$ \\
\hline
\end{tabular}

Means followed by the same letter in the column are not different according to Tukey's test at $5 \%$ of probability.

TABLE 2 - Total antocyanins content of juices from grapes submitted to different doses of UV-C radiation.

\begin{tabular}{c|c}
\hline UV-C dose & Total antocyanins $\left(\mathbf{m g ~ L}^{-1}\right)$ \\
\hline $0 \mathrm{KJ}$ & $273.40 \mathrm{a}$ \\
\hline $0.68 \mathrm{KJ}$ & $234.21 \mathrm{~b}$ \\
\hline $2.73 \mathrm{KJ}$ & $238.21 \mathrm{~b}$ \\
\hline $4.10 \mathrm{KJ}$ & $214.49 \mathrm{~b}$ \\
\hline
\end{tabular}

Means followed by the same letter in the column are not different according to Tukey's test at 5\% of probability. 

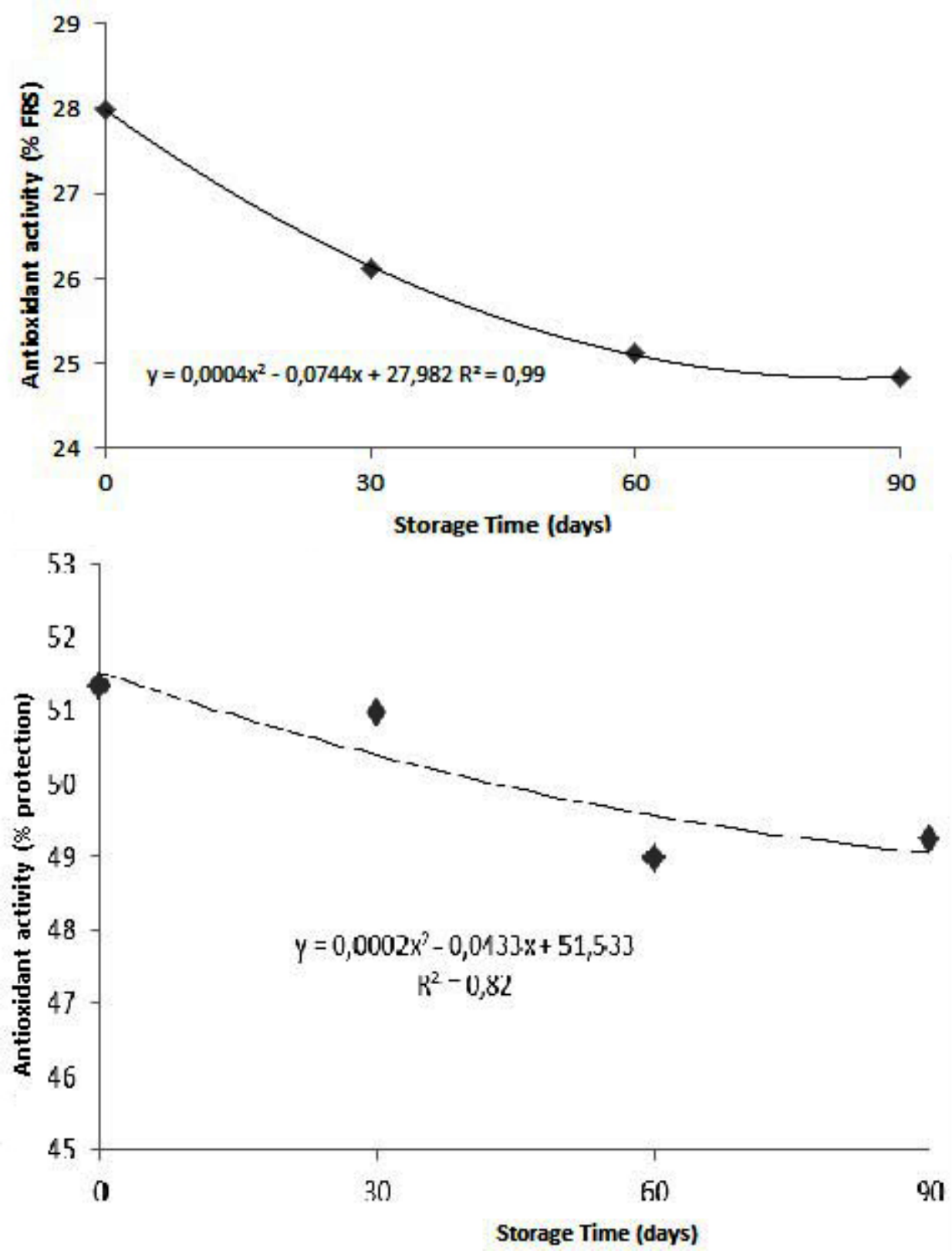

FIGURE 4 - Antioxidant activity (DPPH and b-carotene/linoleic acid methods) of juices from grapes submitted to different doses of UV-C radiation. 


\section{CONCLUSION}

Grape juices cv. Isabel submitted to doses of UV-C radiation did not presented signifficant differences reegarding the antioxidant activity and phenolic compounds. However, the vitamin C content was affected by the UV-C doses, where an increase in values was observed. Thus, it is suggested the use of $\mathrm{UV}-\mathrm{C}$ radiation in grapes $\mathrm{cv}$. Isabel produced in the Minas Gerais State and processed aiming to increase its nutritional value throughout storage.

\section{ACKNOWLEDGMENTS}

The authors would like to thank CNPq, CAPES and FAPEMIG for the supporting the present research.

\section{REFERENCES}

AL BITTAR, S.; PÉRINO-ISSARTIER, S.; DANGLES, O.; CHEMAT, F. An innovative grape juice enriched in polyphenols by microwave-assisted extraction. Food Chemistry, London, v.141, n.3, p.3268-3272, 2013.

ALOTHMAN, M.; BHAT, R.; KARIM, A.A. UV radiation-induced changes of antioxidant capacity of fresh-cut tropical fruits. Innovative Food Science \& Emerging Technologies, Berlin, v.10, n.4, p.212216, 2009.

AOAC - Association of Official Analytical Chemists. Official methods of the Association of the Agricultural Chemists. $8^{\text {th }}$ ed. Gaithersburg, 2007.

BRASIL. Ministério da Agricultura. Portaria no. 544 de 16 de novembro de 1998. Aprova o regulamento técnico para fixação dos padrões de identidade e qualidade para refresco. Diário Oficial [da] República Federativa do Brasil, Brasília, DF,10 nov.1998. Disponível em: $<$ http://oc4j.agricultura. gov.br/agrolegis/do/consultaLei?op=viewTextual\& $\underline{\text { codigo }=1150}>$. Acesso em: 30 abr. 2010.

BRAVO, S.; GARCÍA-ALONSO, J.; MARTÍNPOZUELO, G.; GÓMEZ, V.; SANTAELLA, M.; NAVARRO-GONZÁlEZ, I.; PERIAGO, M.J. The influence of post-harvest UV-C hormesis on lycopene, $\beta$-carotene, and phenolic content and antioxidant activity of breaker tomatoes, Food Research International, Kidlington, v.49, n.1, p.296-302, 2012.
CAPANOGLU, E.; VOS, R.C.H; HALL, R.D.; BOYACIOGLU, D.; BEEKWILDER, J. Changes in polyphenol content during production of grape juice concentrate. Food Chemistry, London, v.139, n.1, p.521-526, 2013.

CHAUHAN, O.P; RAJU, P.S.; RAVI, N.; ROOPA, N.; BAWA, A.S. Studies on retention of antioxidant activity, phenolics and flavonoids in high pressure processed black grape juice and their modeling. International Journal of Food Science and Technology, Washington, v.46, n.12, p.2562-2568, 2011.

DIFFEY, L. D. Sources and measurement of ultraviolet radiation. Methods, San Diego, v.28, n.1, p.4-13, 2002.

DUARTE-ALMEIDA, J.M.; SANTOS, R.J.; GENOVESE, M.I.; LAJOLO, F.M. Avaliação da atividade antioxidante utilizando sistema $\beta$-caroteno/ ácido linoléico e método de seqüestro de radicais DPPH. Ciência e Tecnologia de Alimentos, Campinas, v.26, n.2, p.446-452, 2006.

EVANS, M.; WILSON, D.; GUTHRIE, N.A randomized, double-blind, placebo-controlled, pilot study to evaluate the effect of whole grape extract on antioxidant status and lipid profile, Journal of Functional Foods, London, v.7, n.1, p.680-691, 2014.

FREDERICKS, I.N.; TOIT, M.; KRÜGEL, M. Efficacy of ultraviolet radiation as an alternative technology to inactivate microorganisms in grape juices and wines. Food Microbiology, Cambridge, v.28, n.3, p.510-517, 2011.

GENOVA, G.; IACOPINI, P.; BALDI, M.; RANIERI, A.; STORCHI, P.; SEBASTIANI, L. Temperature and storage effects on antioxidant activity of juice from red and white grapes, International Journal of Food Science and Technology, Glasgow, v.47, n.1, p.13-23, 2012.

GIRARD, B.; MAZZA, G. Produtos funcionales derivados de lã uvas y de lós cítricos. In: MAZZA, G.; ACRIBIA, S.A. Alimentos funcionales: aspectos bioquímicos e de procesado. Zaragoza: Acribia, 1998. cap.5, p.141-182. 
GIUSTI, M.M.; WROLSTAD, R.E. Anthocyanins: characterization and measurement with uv-visible spectroscopy. In: WROLSTAD, R.E.;ACREE, T.E.; AN, H.; DECKER, E.A.; PENNER, M.H.; REID, D.S.; SCHWARTZ, S.J.; SHOEMAKER, C.F.; SPORNS, P. Current protocols in food analytical chemistry. Hoboken: John Willey \& Sons, 2001. cap.1, p.1-13, 2001.

GUERRERO-BELTRAN, J.A.; WELTI-CHANES, J.; BARBOSA-CANOVAS, G.V. Ultraviolet-C light processing of grape, cranberry and grapefruit juices to inactivate Saccharomyces cerevisiae. Journal of Food Process Engineering, London, v.32, n.6, p.916-932, 2009.

HORT, M.A.; SCHULDT, E.Z.; BET, A.C.; DALBO, S.; SIQUEIRA, J.M.; IANSSEN, C; ABATEPAULO, F.; DE SOUZA, H.P.; VELEIRINHO, B; MARASCHIN, M. Anti-atherogenic effects of a phenol-rich fraction from Brazilian red wine (Vitis labrusca L.) in hypercholesterolemic low-density lipoprotein receptor knockout mice. Journal of Medicinal Food, New York, v.15, n.10, 2012.

KRIKORIAN, R.; BOESPFLUG, E.L.; FLECK, D.E.; STEIN, A.L.; WIGHTMAN, J.D.; SHIDLER, M.D.; SADAT-HOSSIENY, S. Concord grape juice supplementation and neurocognitive function in human aging. Journal of Agricultural and Food Chemistry, Washington, v.60, n.23, p.5736-5742, 2012.

LARRAURI, J.A.; RUPÉREZ, P.; SAURACALIXTO, F. Effect of drying temperature on the stabilitity of polyphenols and antioxidant activity of red grape pomace peels. Journal of Agricultural and Food Chemistry, Washington, v.45, n.4, p.13901393, 1997.

LI, S.H.; TIAN, H.B.; ZHAO, H.J.; CHEN, L.H.; CUI, L.Q. The acute effects of grape polyphenols supplementation on endothelial function in adults: meta-analyses of controlled trials. Plos One, Hyderabad, v.8, n.7, 2013.

MELO, E.A.; MACIEL, M.I.S.; LIMA, V.L.A.G.; NASCIMENTO, R.J. Capacidade antioxidante de frutas. Revista Brasileira de Ciências Farmacêuticas, São Paulo, v.44, n.2, p.193-201, 2008.
PALA, C.U.; TOKLUCU, A.K. Effects of UV-C light processing on some quality characteristics of grape juices. Food Bioprocess Technology, New York, v.6, n.3, p.719-725, 2013.

POLONIO, N.C.V.; ROCHA, C.L.M.S.C.; CLEMENTE, E. Trans-resveratrol concentrations and antimutagenic potential of juice from the grape cultivars Vênus, BRS Violeta and Isabel. Genetics and Molecular Research, Ribeirão Preto, v.13, n.1, p.1152-1159, 2014.

RAMESHKUMAR, A.; SIVASUDHA, T.; JEYADEVI, R.; ANANTH, D.A.; PRADEEPHA, G. Effect of environmental factors [air and UV-C irradiation] on some fresh fruit juices. European Food Research Technology, Berlin, v.234, n.6, p.1063-1070, 2012.

RIZZON, L.A.; LINK, M. Composição do suco de uva caseiro de diferentes cultivares. Ciência Rural, Santa Maria, v.36, n.2, p.689-692, 2006.

RIZZON, L.A.; MANFROI, V.; MENEGUZZO, J. Elaboração de suco de uva na propriedade vitícola. Bento Gonçalves: Embrapa Uva e Vinho, 1998.

RUFINO, M.S.M.; ALVES, R.E.; BRITO, E.S.; MORAIS, S.M.; SAMPAIO, C.G.; JIMENEZ, J.P.; SAURA-CALIXTO, F.D. Metodologia científica: determinação da atividade antioxidante total em frutas pela captura do radical livre DPPH. Fortaleza: Embrapa, 2007a. 4p. (Comunicado técnico, 127)

RUFINO, M.S.M.; ALVES, R.E.; BRITO, E.S.; FILHO, J.M. ;MOREIRA, A.V.B. Metodologia científica: determinação da atividade antioxidante total em frutas no sistema $\beta$ caroteno - ácido linoléico. Fortaleza: Embrapa, 2007 b. 4p. (Comunicado técnico, 126)

SCHMATZ, R.; MANN, T.R.; SPANEVELLO, R.; MACHADO, M.M; ZANINI, D.; PIMENTEL, V.C.; STEFANELLO, N.; MARTINS, C.C.; CARDOSO, A.M.; BAGATINI, M.; GUTIERRES, J.; LEAL, C.A.M.; PEREIRA, L.B.; MAZZANTI, C.; SCHETINGER, M.R.; MORSCH, V.M. Moderate red wine and grape juice consumption modulates the hydrolysis of the adenine nucleotides and decreases platelet aggregation in streptozotocin-induced diabetic rats. Cell Biochemistry and Biophysics, Totowa, v.65, n.2, p.129-143, 2013. 
SHEN, Y.; SUN, Y.; QUIAO, L.; CHEN, J.; LIU, D.; YE, X. Effect of UV-C treatments on phenolic compounds and antioxidant capacity of minimally processed Satsuma mandarin during refrigerated storage. Postharvest Biology and Technology, Amsterdam, v.76, n.1, p.50-57, 2013.

SINGLETON, V.L.; ROSSI, J.A. Colorimetry of total phenolics with phosphomolybdic phosphotungstic acid reagents. American Journal of Enology and Viticulture, Davis, v.16, n.3, p.144-158, 1965.

STROECKHER, R.; HENNING, H.M. Analisis de vitaminas: metodos comprobados. Madrid: Paz Montalvo, 1967. 428 p.
VILAS BOAS, A.C; HENRIQUE, P.C.H; LIMA, L.C.O.; NETO, A.D. Antioxidant activity, anthocyanins and organic acids content of grape juices produced in southwest of Minas Gerais, Brazil, Ciência e Agrotecnologia, Lavras, v.38, n.5, p.480486, 2014.

VOLP, A.C.P.; RENHE, I.R.T.; BARRA, K.; STRINGUETA, T.C. Flavonóides antocianinas: características e propriedades na nutrição e saúde. Revista Brasileira de Nutrição Clínica, São Paulo, v.23, n.2, p.141-149, 2008. 